\title{
Effect of seed treatment, soil application and foliar spray of some insecticides on seed quality of bell pepper (Capsicum annuum L.)
}

\author{
Har Lal Meena ${ }^{1}$, Kiran Rana ${ }^{2 *}$, HS Kanwar ${ }^{3}$, Manohar Lal ${ }^{1}$ \\ ${ }^{1}$ Department of Seed Science and Technology, Dr. YS Parmar University of Horticulture and Forestry Nauni, Solan \\ -173230 (H.P.), INDIA \\ ${ }^{2}$ Department of Entomology, Dr. YS Parmar University of Horticulture and Forestry Nauni, Solan - 173230 \\ (H.P.), INDIA \\ ${ }^{3}$ Department of Vegetable Science, Dr. YS Parmar University of Horticulture and Forestry Nauni, Solan - 173230 \\ (H.P.), INDIA \\ *Corresponding author. E-mail: kiranuhf@gmail.com
}

Received: July 28, 2016; Revised received: December 26, 2016; Accepted: August 10, 2017

\begin{abstract}
Studies were carried out to evaluate the efficacy of some insecticides as seed treatment, soil application and foliar sprays on seed quality characters of bell pepper (Capsicum annuumL.) cultivar Solan Bharpur during Kharif season 2013. The treatments comprised of seed application of imidacloprid (Gaucho 600FS) and thiamethoxam (Cruiser 70WS), soil application of neem cake@ 2 q/acre and carbofuran @ 6 kg/acre and foliar sprays of imidacloprid (Confidor $200 \mathrm{SL}$ ), thiamethoxam (Actara 25 WS), indoxacarb14.5 SC @ 0.5ml/l, NSKE (neem seed kernel extract) @ 5\%, Neem Raj 500ppm @ 2.5ml/l and control. The observations regarding quality parameters recorded were germination percentage, seedling length, seeding dry weight, seed vigour index-I, seed vigour index-II and electrical conductivity. The results revealed that treatment combination viz., seed treatment and foliar spray with thiamethoxam $\left(\mathrm{S}_{2} \mathrm{~F}_{2}\right)$ recorded significantly higher germination percentage (96.33\%), seed vigour index-I (934.10), seed vigour index-II (245.02) and minimum electrical conductivity $\left(216.67 \mathrm{dSm}^{-1}\right)$ at 0.05 level of significance. Therefore, seed treatment and foliar spray of thiamethoxam may be recommended for quality seed production of bell pepper.
\end{abstract}

Keywords: Capsicum, Cultivar, Electrical conductivity, Germination, Seed vigour

\section{INTRODUCTION}

Bell pepper (Capsicum annuum L.) is an important solanaceous vegetable crop grown almost all over the world. It holds a significant place among vegetables because of its high nutritional value; rich source of ascorbic acid as only $50 \mathrm{~g}$ of green fruit can meet the daily requirement of an individual (McGillivray, 1953) and also rich in minerals such as iron, potassium, calcium, magnesium, phosphorus, sodium and selenium (Agarwal et al., 2007). Bell pepper is originated in Mexico with secondary centre in Guatemala (Bukasov, 1930; Smith and Heiser, 1957) and was introduced in India by the Britishers in the $19^{\text {th }}$ century in Shimla hills. In India, bell pepper is grown in Himachal Pradesh, Jammu and Kashmir, Uttrakhand, Arunachal Pradesh and Darjeeling district of West Bengal during summer months and as autumn crop in Maharashtra, Karnataka, Tamil Nadu and Bihar. The mild climate with humid environmental condition of Himachal Pradesh during the summer season is best suited for off season cultivation of bell pepper for fresh fruit and seed production.

Seed is the most important input in agricultural production. India has diverse climate and agro-climatic conditions of the plains are not congenial for seed production of bell pepper due to various biotic (pests and diseases), abiotic (rainfall, temperature etc.) and crop factors like flower and fruit drop (Lal et al., 2014). Like other vegetables, the seed yield and quality attributes (germination, vigour)of bell pepper are greatly influenced by these factors. Among the biotic factors insect pests are important which cause heavy loss to the crop of which sucking pests and fruit borers which not only affect the seed yield but the seed quality is greatly hampered. Plant protections measures when taken up through seed treatment, soil application and foliar spray are known to manage these pests effectively and in turn enhance the seed yield and quality. Although chemical control of various insect pests of bell pepper for vegetable production is well documented yet very few studies on seed treatment, soil application with synthetic insecticides and botanicals for the management of insect pests and their effect on seed yield and quality are carried out in Himachal Pradesh and elsewhere in India. Keeping all this in view, the present studies have been undertaken to evaluate the effect of some commonly used insecticides and bo- 
tanicals on seed quality of bell pepper(Capsicum annuum L.).

\section{MATERIALS AND METHODS}

The experiment was carried out at Department of Seed Science and Technology, Dr YS Parmar University of Horticulture and Forestry, Nauni, Solan, HP during Kharif, 2013. The seedlings were transplanted in a plot having size of $5.4 \mathrm{~m}^{2}(2.40 \mathrm{~m} \times 2.25 \mathrm{~m})$ in Randomized Complete Block Design with three replicates. FYM and fertilizers were applied as per recommendations of package of practices, Directorate of Extension Education of the university (FYM @ 200 quintal/ha, CAN@400 Kg/ha, SSP@475 Kg/ha and MOP@90 Kg/ha). The treatments comprised 24 different combinations of two seed treatments viz. $\mathbf{S}_{1}$ (Imidacloprid-Gaucho 600FS @ $12 \mathrm{ml} / \mathrm{kg}$ ) and $\mathrm{S}_{2}$ (Thiamethoxam-Cruiser 70WS@10g/kg) three days prior to sowing; two soil treatments viz. Neem cake $\left(\mathrm{S}_{3}\right)$ and Carbofuran $\left(\mathrm{S}_{4}\right) @ 270 \mathrm{~g} /$ plot $(13.5 \mathrm{~g} / \mathrm{plant})$ and $8.1 \mathrm{~g} /$ plot $(0.405 \mathrm{~g} / \mathrm{plant})$ at the time of seedling transplantation; and six foliar sprays viz., $\mathrm{F}_{1}$ (Imidacloprid)@0.5ml/1, $\mathrm{F}_{2}$ (Thiamethoxam - Actara 25 WS)@0.40 g/l, F (Indoxacarb14.5 SC)@0.5ml/1, $\mathrm{F}_{4}$ (NSKE)@5 per cent and $\mathrm{F}_{5}$ (Neem Raj 500ppm)@ $2.5 \mathrm{ml} / 1$ first at 30 days after transplanting and second at 15 days after the first spray and $F_{6}$ i.e. control (without any spray).

The samples were collected from five plants randomly selected from every plot of each treatment $(4 \mathrm{~S} \times 6 \mathrm{~F}=24$ treatments $\mathrm{x} 3$ replications $=72$ plots). Red ripe fruits were harvested from selected plants, seeds extracted and dried to eight per cent moisture content. The germination test was conducted with 100 seeds from each plot in five replications by using petri plate method as per ISTA Rules (Anonymous, 1985). The root length and shoot length of ten normal seedlings were measured on the $7^{\text {th }}$ day. The seed vigour index-length (SVI-I) was calculated by adopting the method suggested by Abdul-Baki and Anderson (1973) as Seed vigour index-I (SVI-I) = Germination (\%) $x$ seedling length $(\mathrm{cm})$. Dry weight of seedlings was measured by taking the ten normal seedlings used for root and shoot length. The seedlings were kept in blotting paper and dried in hot air oven maintained at $75^{\circ} \mathrm{C}$ for 24 hours. The dried seedlings were cooled in a desicator for 60 minutes, then seedlings were weighed in an electronic balance and the weight was expressed in mg as dry weight of ten seedlings. Seed vigour index-II (SVI-II) was calculated as SVI-II = Germination (\%) x seedling dry weight (mg).

Electrical conductivity variations were observed using 25 seeds per replication of each treatment combination. Seeds were soaked in $25 \mathrm{ml}$ of distilled water for 24 hours. After the expiry of the said period electrical conductivity was measured using the digital conductivity meter (EUTECH Instruments: CON 700
Conductivity / ${ }^{0} \mathrm{C} /{ }^{0} \mathrm{~F}$ meters) and the results were expressed as $\mathrm{dSm}^{-1}$. The statistical analysis of the data recorded was done as per design of the experiments as suggested by Gomez and Gomez (1984).

\section{RESULTS AND DISCUSSION}

The quality of the seed is the ultimate attribute that determines the seedling performance in the field under various biotic and abiotic stresses. Seed vigour is one of the factor that determines the seed quality. Bold and vigorous seeds give better plant stand and further growth of plants and fruits. Data on different seed quality characters of capsicum has been recorded and presented in Table $1 \& 2$. The germination percentage of capsicum seeds differed significantly due to seed and soil treatments at 0.05 level of significance. Significantly higher germination (86.61\%) was recorded in seeds treated with thiamethoxam $\left(\mathrm{S}_{2}\right)$ followed by seeds treated with imidacloprid $\left(\mathrm{S}_{1}\right)$ $(83.22 \%)$, soil application of neem cake $\left(\mathrm{S}_{3}\right)(81.28 \%)$ and soil application of carbofuran $\left(\mathrm{S}_{4}\right)(78.72 \%)$. Irrespective of seed and soil treatments, the foliar spray of thiamethoxam $\left(\mathrm{F}_{2}\right)$ recorded significantly higher germination $(91.25 \%)$ at $\mathrm{p}<0.05$ followed by imidacloprid $\left(F_{1}\right)$ which recorded 87.25 per cent seed germination. All the treatment combinations of seed or soil application with foliar sprays resulted in improved seed germination over control i.e. crop raised with seed or soil application but without foliar sprays. However, treatment combination seed treatment and foliar spray of thiamethoxam $\left(\mathrm{S}_{2} \mathrm{~F}_{2}\right)$ recorded significantly higherseed germination $(96.33 \%)$ followed by seed treatment with imidacloprid and foliar spray of thiamethoxam $\left(\mathrm{S}_{1} \mathrm{~F}_{2}, 92.33 \%\right)$, seed treatment with thiamethoxam and foliar spray of imidacloprid $\left(\mathrm{S}_{2} \mathrm{~F}_{1}\right.$, $91.00 \%$ ) whereas the minimum germination $(65.33 \%)$ was observed in soil application with carbofuran without any foliar spray $\left(\mathrm{S}_{4} \mathrm{~F}_{6}\right)$. It is evident from the present study that physically and physiologically sound seeds produced from the treated seeds and sprayed plants for insect's control lead to high and uniform germination. These results are in conformity with Almeida et al. (2009) who reported an increased expression of seed germination with thiamethoxam and imidacloprid in carrot seeds. In soyabean, pea and some other crops Horii et al. (2007) and Cataneo et al. (2010) also reported similar results with thiamethoxam (Cruiser).

Seedling length and dry weight indicates the strength of seed and are the important attributes of the seed vigour. Seed treatment with thiamethoxam $\left(\mathrm{S}_{2}\right)$ resulted in significantly higher seedling length $8.21 \mathrm{~cm}$ at $\mathrm{p}<0.05$ followed by seed treatment with imidacloprid $\left(\mathrm{S}_{1}\right) 8.05 \mathrm{~cm}$, soil application of neem cake $\left(\mathrm{S}_{3}\right) 7.87 \mathrm{~cm}$ and soil application of carbofuran 


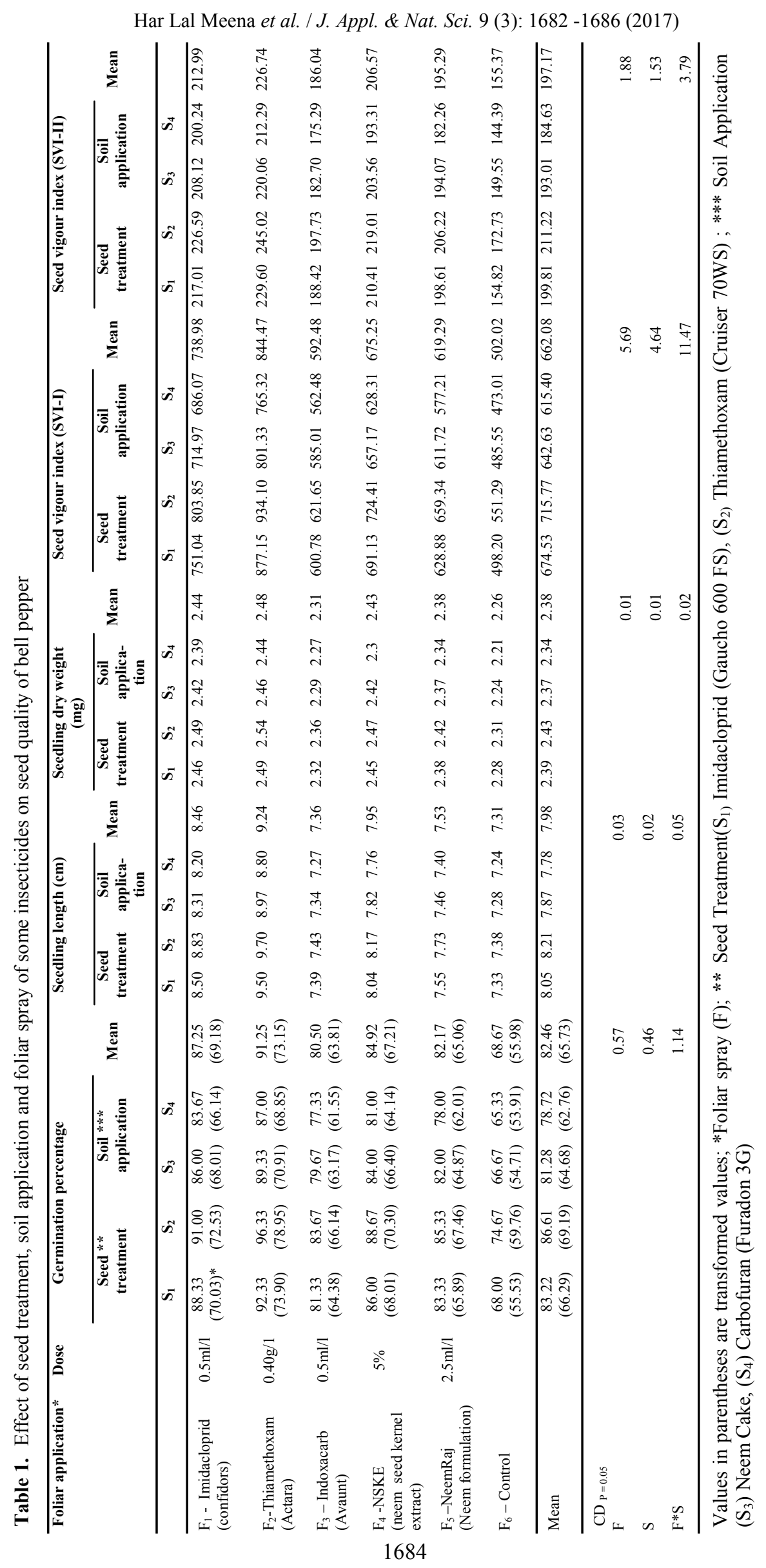


Har Lal Meena et al. / J. Appl. \& Nat. Sci. 9 (3): 1682 -1686 (2017)

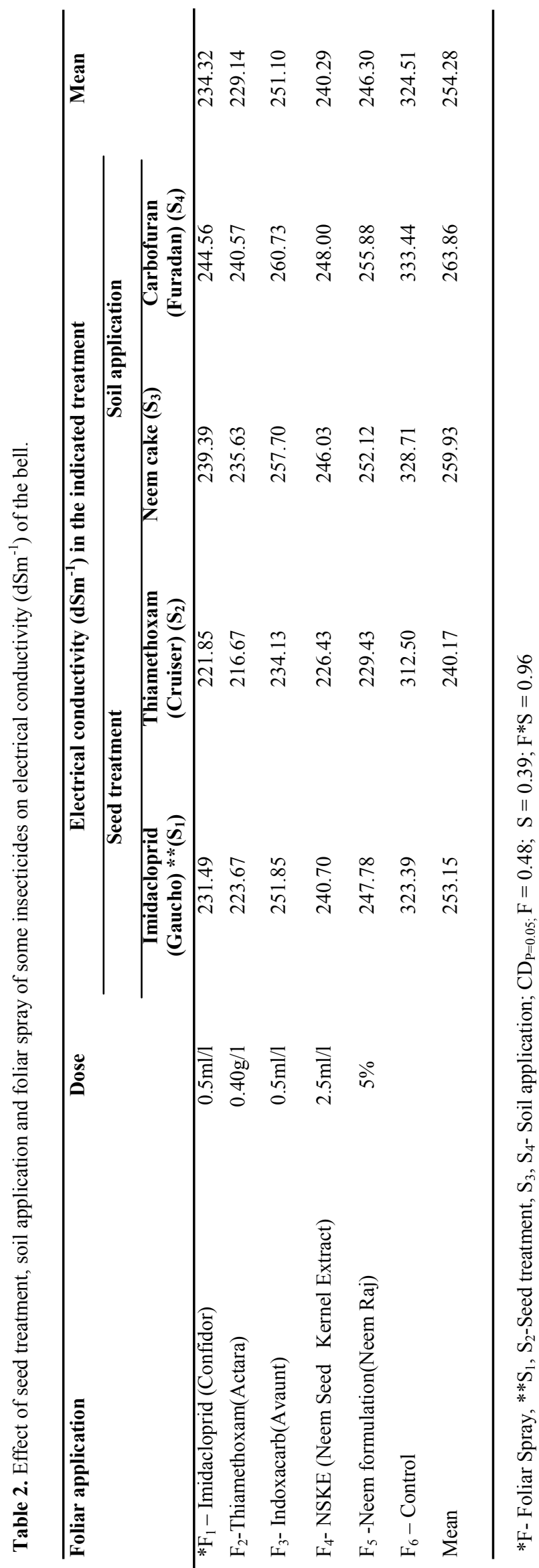

$\left(\mathrm{S}_{4}\right) 7.78 \mathrm{~cm}$.Irrespective of seed and soil treatments, foliar spray of thiamethoxam $\left(\mathrm{F}_{2}\right)$ lead to significantly higher seedling length $(9.24 \mathrm{~cm})$ followed by imidacloprid $\left(\mathrm{F}_{1}\right)$ which recorded $8.46 \mathrm{~cm}$ seedling length,. The interaction of seed treatment and foliar spray $\left(\mathrm{S}_{2} \mathrm{~F}_{2}\right)$ resulted in significantly higher seedling length $(9.70 \mathrm{~cm})$. Similar results were obtained for seedling dry weight which showed that seed treatment and foliar spray of thiamethoxam $\left(\mathrm{S}_{2} \mathrm{~F}_{2}\right)$ recorded significantly higher seedling dry weight $(2.54 \mathrm{mg})$ (table.1). The healthy seeds produced from treated plants lead to vigorous seedling having more length and dry weight. These results are in close conformity with Cataneo et al. (2006) who observed that thiamethoxam accelerated germination, induced more growth of the embryonic axis and minimized the negative effects in presence of aluminium, salinity and water deficiency in soyabean seeds.

Seed vigour is the sum total of all those properties of seeds which determine the potential level of performance and activity of a non- dormant seed during germination and seedling emergence (Perry, 1978). It was observed that seed vigour index-I (SVI-I) was significantly influenced by all treatment combinations of these insecticides (Table 1).Seed treatment with thiamethoxam $\left(\mathrm{S}_{2}\right)$ recorded significantly higher SVI-I (715.77)followed by seed treatment with imidacloprid (674.53), soil application of neem cake (642.63) and soil application of carbofuran (615.40).Irrespective of seed or soil treatments, foliar spray of thiamethoxam $\left(\mathrm{F}_{2}\right)$ recorded significantly higher SVI-I (844.47). Next best treatment was imidacloprid $\left(\mathrm{F}_{1}\right)$ which recorded 738.98 SVI-I.Among all treatment combinations, seed treatment and foliar spray of thiamethoxam $\left(\mathrm{S}_{2} \mathrm{~F}_{2}\right)$ recorded significantly higher SVI-I (934.10)at $\mathrm{p}<0.05$ whereas the least seed vigour (473.01) was recorded in soil application of carbofuran without any spray. Data pertaining to seed vigour index- II (SVI-II) showed similar results. The seed treatment with thiamethoxam $\left(\mathrm{S}_{2}\right)$, foliar spray of thiamethoxam $\left(\mathrm{F}_{2}\right)$ and treatment combination viz., seed treatment and foliar spray of thiamethoxam $\left(\mathrm{S}_{2} \mathrm{~F}_{2}\right)$ gave significantly higher 211.22 , 226.74 and 245.02 SVI-II, respectively.These results are in conformity with Horii et al. (2007) and Cataneo et al. (2010) who reported that seed treatment and subsequent foliar spray of thiamethoxam and imidacloprid significantly increased the seed germination and vigour in soyabean, pea and some other crops.Almeida et al. (2009) recorded increased vigour of carrot seeds and reported that thiamethoxam and imidacloprid act as bio-activators and stimulates the physiological performance of seeds. These results are also in agreement with Stevens et al. (2008) and Moser and Obrycki (2009) who reported that seed treatment and subsequent foliar spray of thiamethoxam and imidacloprid resulted in higher germination and 
vigour in soyabean, wheat and corn seeds.

Electrical conductivity is a major factor that indicates the vigour of the seed. Electrical conductivity is characterized by the total leachates or reserves from the seed. Sound seeds having intact integuments resulted in least leachates when soaked in water and weaker seeds having ruptured or degraded seed coat resulted in more leachates. The seeds having more leachates are less vigorous than those having less leachates. In the present studies, the electrical conductivity differed significantly due to seed, soil and foliar treatments. The mean electrical conductivity was recorded significantly lowest in seed treatment with thiamethoxam $\left(\mathrm{S} 2,240.17 \mathrm{dSm}^{-1}\right)$ and the foliar spray of thiamethoxam (F2, $\left.229.14 \mathrm{dSm}^{-1}\right)$ as compared to other treatments. The treatment combination viz., seed treatment and foliar spray of thiamethoxam $\left(\mathrm{S}_{2} \mathrm{~F}_{2}\right)$ recorded significantly minimum electrical conductivity (216.67 $\mathrm{dSm}^{-1}$ ) and maximum electrical conductivity $333.44 \mathrm{dSm}^{-1}$ was observed in soil application with carbofuran without any foliar spray $\left(\mathrm{S}_{4} \mathrm{~F}_{6}\right)$. This indicated that plant protection through seed treatment and foliar sprays at appropriate time lead to healthy growth of plants and resulted in sound, intact and vigorous seeds. These findings concur with those of Pataky et al. (2000) who reported that maize seeds treated with the insecticide thiamethoxam decreased the incidence of Stewart's wilt. The results are also in close agreement with Kandolo (2008) who reported improved or maintained vigour in maize seeds treated with Apron ${ }^{\circledR}$ Star 42 WS (thiamethoxam, metalaxy-m and difenoconazole), which was indicated by a reduced or equivalent solute leakage following fast imbibition. The reduced number of diseased plants in the Apron ${ }^{\circledR}$ Star 42 WS treatment may be due to its broad spectrum activity against many pests and diseases.

\section{Conclusion}

Seed treatment with thiamethoxam (Cruiser)@10 g per kg seed and two foliar sprays of thiamethoxam (Actara)@0.40g / , first spray after thirty days of transplanting and second after fifteen days of first spray, were found effective in managing insect pests and resulted in production of high quality seeds in bell pepper. Therefore, seed treatment with thiamethoxam (Cruiser) and two foliar sprays of thiamethoxam (Actara) may be recommended after multiyear and multi location trials for quality seed production in capsicum.

\section{REFERENCES}

Abdul Baki, A. A. and Anderson, J. D. (1973). Vigour determination in soyabean seed by multiple criteria. Crop
Science, 13: 630-633

Agarwal, A., Gupta, S. and Ahmed, Z. (2007). Influence of plant densities on productivity of bell pepper (Capsicum annuиm L.) under greenhouse in high altitude cold desert of Ladakh. International Symposium on Medicinal and Nutraceutical Plants, 756: 309-314

Almeida, A. S., Tillmann, M. A. A., Villela, F. A. and Pinho, M. S. (2009). Bioativador no desempenhofisiologico de sementes de cenoura. Revista Brazileira de Sementes, pp.87-95

Anonymous. (1985). ISTA (International Seed Testing Association). International rules for seed testing. Seed Science and Technology, 13: 300-520

Bukasov, S. M. (1930). The cultivated plants of Mexico, Guatemala and Columbia. Bulletin of Applied BotanyGenetics and Plant Breeding,47: 261-273

Cataneo, A. C., Andreo, A. E., Seiffert, M. E., Bufalo, J. and Feirreira, L. C.(2006). Action of Cruiser insecticide on germination of soyabean seeds under stress condition. In: Brazilian Congress of Soyabean, p. 90

Cataneo, A. C., Ferreira, L. C., Carvalho, J. C., Andréo-Souza, Y., Corniani, N., Mischan, M. M. and Nunes, J. C. (2010). Improved germination of soybean seed treated with thiamethoxam under drought conditions. Seed Science and Technology, 38(1): 248-251

Gomez, K. A. and Gomez, A. A. (1984). Statistical procedure for agricultural research. New York John willy \& sons. $690 \mathrm{p}$

Horii, A., McCue, P. and Shetty, K. (2007). Enhancement of seed vigour following insecticide and phenolic elicitor treatment. Bioresource Technology, 98(3): 623-632

Kandolo, S. D. (2008). Effect of fungicide seed treatments on germination and vigour of maize seed. M.Inst. Agrar. (Plant Protection). University of Pretoria, Pretoria.

Lal, M., Kanwar, H. S. and Kanwar, R. (2014). Impact of spacing and training on seed yield of capsicum, Capsicum annuиm L. under protected conditions. International Journal of Farm Sciences, 4(3): 42-48

McGillivray J.H. (1953). Vegetable Production. Blaskinston and Co., New York, 387p

Moser, S. E. and Obrycki, J. J. (2009). Non-target effects of neonicotinoid seed treatments; mortality of coccinellid larvae related to zoophytophagy. Biological Control, 51 (3): 487-492

Pataky, J. K., Michener, P.M., Freeman, N.D., Weinzierl, R.A., \& Teyker, R.H. (2000). Control of Stewart's wilt in sweet corn with seed treatment insecticides. Plant Disease, 84: 1104-1108

Perry, D. A. (1978). Report of the vigour test committee. Seed Science Technology, 6: 159-81

Smith, P. G. and Heiser, C. B. (1957).Breeding behaviour of cultivated peppers. Proceedings of American Society of Horticulture Science, 10: 286-290

Stevens, D., Warne, M. S., Heemsbergen, D., McLaughlin, M., Cozens, G., Whatmuff, M., Broos, K., Barry, G., Bell, M., Nash, D. and Pritchard, D. M. (2008). The toxicity of copper and zinc salts to wheat in 14 soils. Environmental Toxicology and Chemistry, 27(4): 786792 